\title{
RESISTENSI Eleusine indica TERHADAP GLIFOSAT PADA PERKEBUNAN KELAPA SAWIT DI KABUPATEN BATU BARA
}

\author{
Koko Tampubolon $^{1 *}$, Edison Purba ${ }^{2)}$, dan Diana Sofia Hanafiah ${ }^{2)}$ \\ 1)Program Doktor Ilmu Pertanian, Fakultas Pertanian, Universitas Sumatera Utara, Padang Bulan, Medan 20155, Indonesia. \\ ${ }^{2}$ Program Studi Agroteknologi, Fakultas Pertanian, Universitas Sumatera Utara, Padang Bulan, Medan 20155, Indonesia. \\ "Email : koko.tampubolon@gmail.com
}

\begin{abstract}
ABSTRAK
Populasi Eleusine indica dari perkebunan kelapa sawit di Kabupaten Batu Bara secara menyeluruh belum pernah dilaporkan resisten-glifosat. Penelitian ini bertujuan untuk melaporkan sebaran populasi dan mengklasifikasi resistensi $E$. indica terhadap herbisida glifosat pada perkebunan kelapa sawit di Kabupaten Batu Bara. Penelitian ini dilaksanakan di Lahan Pusat Penelitian Gulma Fakultas Pertanian Universitas Sumatera Utara pada Oktober 2016 - Agustus 2017. Penelitian ini menggunakan glifosat dengan dosis rekomendasi $720 \mathrm{~g}$ b.a.ha ${ }^{-1}$ dan tiga ulangan. Populasi ESU (dari Lapangan Bola Politeknik Negeri Medan) sebagai pembanding. Analisis data menggunakan software IBM SPSS Statistics 20. Hasil penelitian menunjukkan bahwa populasi E. indica yang paling resisten $(63,33 \%)$ pada perkebunan kelapa sawit di Kabupaten Batu Bara terdapat pada ESU ${ }_{4.11}$ (afdeling 4 Kebun Tanah Gambus). Populasi $E$. indica yang tergolong resisten-glifosat 83,33\% (10 populasi), tergolong moderat resisten-glifosat $16,67 \%$ (2 populasi) dan tidak ada populasi yang sensitif-glifosat pada dosis rekomendasi $720 \mathrm{~g}$ b.a.ha ${ }^{-1}$ pada perkebunan kelapa sawit di Kabupaten Batu Bara.
\end{abstract}

Kata Kunci: Eleusine indica, Glifosat, Kabupaten Batu Bara, Resisten.

\section{PENDAHULUAN}

Kehadiran gulma Eleusine indica (L.) Gaertn di areal perkebunan kelapa sawit akan mempengaruhi kualitas dan kuantitas produksi kelapa sawit serta menambah biaya input perkebunan. Ampong-Nyarko et al. (1992) mengatakan bahwa gulma ini tergolong tumbuhan C4 dan pertumbuhannya sangat cepat pada kondisi intensitas cahaya penuh. Ganeshaiah and Umashaanker, (1982); Mysore and Baird, (1997) juga mengatakan $E$. indica merupakan gulma semusim yang melakukan penyerbukan sendiri dan memiliki 2 set kromosom (diploid), dan ukuran genom relatif kecil sekitar 8,03 x $10^{8} \mathrm{bp}$. Chin, (1979) juga mengatakan gulma ini menghasilkan biji hingga 140.000 per tanaman.

Intensitas cahaya matahari penuh pada perkebunan kelapa sawit di Indonesia terdapat pada tahap pembibitan sampai tanaman belum menghasilkan (TBM). Berdasarkan pengamatan dilahan percobaan, E. indica memiliki pertumbuhan dan perkembangan yang tergolong cepat dari masa perkecambahan sampai menghasilkan biji hanya memerlukan waktu \pm 2 bulan. Hal ini mengakibatkan keberadaan populasi $E$. indica pada pembibitan sampai tanaman belum menghasilkan tersebut lebih dominan dibandingkan pada tanaman kelapa sawit menghasilkan (TM). Secara umum, pengendalian gulma diperkebunan kelapa sawit menggunakan herbisida dengan rotasi pengendalian (pusingan) sekali dalam 3-4 bulan. Salah satu herbisida yang sering digunakan perkebunan kelapa sawit dalam mengendalikan gulma yaitu glifosat.

Bahan aktif yang terdapat pada herbisida glifosat yaitu N-(phosphonomethyl) glisin yang merupakan turunan asam amino glisin dan asam fosfonat. Glifosat umumnya digunakan sebagai herbisida purna tumbuh bersifat non-selektif yang dapat mengendalikan berbagai jenis gulma semusim dan tahunan. Glifosat menghambat enzim 5enolpyruvylshikimate-3-phosphate synthase (EPSPS) yang terjadi di jaringan kloroplas tanaman dan mengubah shikimate-3-phosphate (S-3-P) menjadi enolpyruvylshikimate-3-phosphate (EPSP) dan akhirnya mengarah pada produksi asam amino, fenilalanin dan tirosin, serta triptofan. Shikimate-3phosphate (S-3-P) tidak dapat dikonversi menjadi EPSP dikarenakan S-3-P tidak stabil, maka cepat dikonversi menjadi shikimat yang lebih stabil dan terakumulasi (Monaco et al. 2002). 
Penggunaan herbisida dengan bahan aktif yang sama secara berkali-kali dengan periode waktu yang lama dapat menyebabkan gulma menjadi resisten. Jika gulma tersebut sudah resisten maka lebih sulit untuk dikendalikan (Purba, 2009). Menurut Knezavic et al. (2017) menyatakan bahwa gulma resisten herbisida merupakan spesies gulma yang memiliki kemampuan berkembang untuk bertahan hidup setelah dikendalikan menggunakan herbisida. Penggunaan herbisida yang sama secara intensif dan terus-menerus selama beberapa dekade terakhir akan menghasilkan evolusi gulma resisten herbisida. Perubahan itu biasanya dalam bentuk mutasi gen atau perubahan dalam metabolisme tumbuhan yang menyebabkan resistensi terhadap herbisida tertentu atau group herbisida dari mode of action yang sama. Terdapat 3 level resistensi herbisida, yaitu : (1) resistensi tunggal terjadi ketika gulma resisten hanya satu group herbisida dan/atau satu mode of action (misalnya resisten terhadap glifosat), (2) resistensi silang terjadi ketika gulma resisten terhadap satu atau lebih group herbisida dengan mode of action yang sama (misalnya resisten terhadap herbisida sulfonylurea dan imidazolinone, keduanya termasuk dalam mode of action ALS), (3) resistensi ganda terjadi ketika gulma resisten terhadap lebih dari dua group herbisida dan lebih dari dua mode of action herbisida (misalnya resisten terhadap Pursuit (ALS) dan Roundup (glifosat).

Kegiatan pengendalian gulma di perkebunan kelapa sawit di Sumatera Utara secara berulang-ulang ini akan meningkatkan evolusi E. indica resistenherbisida. Beberapa hasil penelitian telah melaporkan E. indica telah mengalami resisten-glifosat pada perkebunan kelapa sawit di Sumatera Utara, namun belum pernah dilaporkan di Kabupaten Batu Bara. Kabupaten Batu Bara pada tahun 2015 mempunyai luas lahan perkebunan negara (2.401 ha) yang terdiri dari 277 ha (TBM), 1.880 ha (TBM), 244 ha (replanting) (Direktorat Jenderal Perkebunan, 2017). Diperlukan sumber informasi awal dalam mengendalikan $E$. indica berupa laporan pemetaan resistensi. Tujuan penelitian ini adalah untuk melaporkan sebaran populasi dan mengklasifikasi resistensi $E$. indica terhadap herbisida glifosat pada perkebunan kelapa sawit di Kabupaten Batu Bara.

\section{METODE PENELITIAN}

Koleksi Biji Eleusine indica Resisten dan Sensitif. Biji E. indica dari beberapa afdeling pada perkebunan kelapa sawit di Kabupaten Batu Bara (Tabel 1) dikumpulkan dengan cara mengambil biji diantara baris tanaman kelapa sawit dengan kriteria sudah matang ditandai warna malai sudah kecokelatan sebanyak 50 rumpun per lokasi afdeling setiap kebun. Biji gulma dimasukkan kedalam amplop coklat dan diberi keterangan.

Tabel 1. Populasi E. indica yang diambil di beberapa afdeling pada perkebunan kelapa sawit

\begin{tabular}{clcl} 
No. & Kode Sampel & Afdeling & \multicolumn{1}{c}{ Nama Kebun } \\
\hline 1 & ESU $_{3.13}$ & 1 & Kebun Tanah Itam Ulu \\
2 & ESU $_{3.14}$ & 2 & Kebun Tanah Itam Ulu \\
3 & ESU $_{3.15}$ & 4 & Kebun Tanah Itam Ulu \\
4 & ESU $_{4.8}$ & 1 & Kebun Tanah Gambus \\
5 & ESU $_{4.9}$ & 2 & Kebun Tanah Gambus \\
6 & ESU $_{4.10}$ & 3 & Kebun Tanah Gambus \\
7 & ESU $_{4.11}$ & 4 & Kebun Tanah Gambus \\
8 & ESU $_{5.12}$ & 1 & Kebun Dolok Estate \\
9 & ESU $_{5.13}$ & 2 & Kebun Dolok Estate \\
10 & ESU $_{5.14}$ & 3 & Kebun Dolok Estate \\
11 & ESU $_{5.15}$ & 4 & Kebun Dolok Estate \\
12 & ESU $_{5.16}$ & 5 & Kebun Dolok Estate \\
\hline Keterangan : ESU (Eleusine indica Sumatera Utara)
\end{tabular}

Keterangan : ESU (Eleu sine indica Sumatera Utara)

Pengambilan biji gulma yang sensitif ( $\mathrm{ESU}_{0}$ ) diambil dari Lapangan Bola Politeknik Negeri Medan, dimana herbisida tidak pernah diaplikasikan sebelumnya (Tampubolon and Purba, 2018 ${ }^{\mathrm{b}}$ ). Penelitian ini dilaksanakan pada Oktober 2016 - Agustus 2017.

Pematahan Dormansi Biji. Pematahan dormansi biji $E$. indica terlebih dahulu direndam dalam larutan kalium nitrat $\left(\mathrm{KNO}_{3}\right)$ dengan konsentrasi 0,2\% selama 30 menit (Ismail et al. 2002). Perendaman ini bertujuan untuk mematahkan dormansi sekunder biji $E$. indica.

Pengecambahan dan Pindah Tanam. Media kecambah yang digunakan adalah topsoil dan pupuk kandang yang sudah diayak dengan perbandingan volume 1:1. Setelah dicampur secara merata, media diovenkan dengan suhu $100^{\circ} \mathrm{C}$ selama 3 jam yang bertujuan untuk menghindari seedbank E. indica. Media tumbuh dimasukkan kedalam bak perkecambahan yang berukuran $33 \mathrm{~cm} \times 24 \mathrm{~cm}$ dan sudah diberi kode sumber lokasi pengambilan sampel. Penanaman pada bak kecambah dilakukan di rumah plastik lahan percobaan Fakultas Pertanian USU. Tiga hari setelah dikecambahkan, media perkecambahan disemprot 
dengan insektisida untuk mencegah serangan semut merah terhadap biji gulma. Penyiraman dilakukan pada sore hari dengan menggunakan gembor yang lubangnya halus agar akar bibit tidak terbongkar dari media tanam.

Setelah bibit $E$. indica berdaun 2-3 helai, bibit dipindah tanam kedalam pot dengan media tanam topsoil, pasir dan pupuk kandang yang sudah diayak dengan perbandingan volume 1:1:1. Jumlah bibit $E$. indica yang dipindahkan sebanyak 10 bibit per pot dan ditanam secara menyebar merata. Kemudian dipelihara ditempat berbeda di Lahan Pusat Penelitian Gulma Fakultas Pertanian USU. Penyiraman dilakukan pada sore hari. Setiap E. indica dari lokasi yang berbeda disusun dalam rancangan acak kelompok (RAK) dengan tiga ulangan.

Pengaplikasian Herbisida Glifosat. Pengaplikasian glifosat dilakukan dengan dosis rekomendasi $720 \mathrm{~g}$ b.a.ha' ${ }^{-1}$ (setara dengan 21 ha $^{-1}$ ). Sebelum dilakukan penyemprotan, dilakukan kalibrasi spayer. Kalibrasi penyemprotan yang diperoleh sebesar 2921 ha $^{-1}$. Penyemprotan glifosat dilakukan saat gulma berdaun 3 - 4 helai (Hess et al. 1997). Penyemprotan dilakukan pada waktu cuaca cerah dan diusahakan mengenai seluruh tajuk gulma.

Analisis Data. Parameter yang diamati antara lain: mortalitas, jumlah $E$. indica bertahan hidup, bobot kering dan kategori resistensi. Pengamatan dilakukan pada 21 hari setelah aplikasi (21 HSA) (Jalaludin et al. 2015). E. indica yang hidup sampai minggu ke-6 setelah aplikasi, dipotong tepat pada leher akar (permukaan tanah) dari masing-masing pot. Kemudian diovenkan pada temperatur $80^{\circ} \mathrm{C}$ selama 48 jam (SERAS, 1994) untuk memperoleh bobot kering yang konstan. Lalu ditimbang dengan menggunakan timbangan analitik.

Persentase $E$. indica bertahan hidup

$$
=\frac{\sum E \text {.indica yang bertahan hidup }}{\sum E \text {.indica yang ditanam }} \times 100 \%
$$

Mortalitas E. Indica

$$
=\frac{\sum \text { E.indica } \text { yang mati }}{\sum \text { E.indica yang ditanam }} \times 100 \%
$$

Klasifikasi resistensi diukur dari persentase mortalitas populasi E. indica. Klasifikasi sensitif-glifosat (S) jika persentase mortalitas E. indica $>98-100 \%$, klasifikasi moderat resisten glifosat (MR) jika persentase mortalitas E. indica $>$ 80-98\%, dan klasifikasi resisten-glifosat (R) jika persentase mortalitas E. indica d" $80 \%$ (Owen and Powles,
2009). Pengujian data dalam penelitian ini menggunakan software IBM SPSS Statistics 20.

\section{HASIL DAN PEMBAHASAN}

Persentase populasi E. indica yang bertahan hidup terhadap herbisida glifosat pada dosis $720 \mathrm{~g}$ b.a.ha${ }^{1}$ dari perkebunan kelapa sawit di Kabupaten Batu Bara dapat dilihat Gambar 1. Diperoleh resisten-glifosat berkisar 23,33-63,33\%, moderat resisten-glifosat berkisar 13,33-14,81\% dan tidak ada populasi E. indica dari beberapa afdeling pada perkebunan kelapa sawit di Kabupaten Batu Bara telah populasi sensitif-glifosat.

Populasi E. indica yang paling resisten $(63,33 \%)$ terdapat pada ESU $_{4.11}$ (afdeling 4 Kebun Tanah Gambus). Hal ini disebabkan glifosat yang sering digunakan pada kebun ini mengakibatkan $E$. indica mengalami perubahan enzim EPSPS sehingga sulit untuk dikendalikan. Hubungan persentase populasi E. indica yang bertahan hidup dengan bobot kering dalam penelitian ini bersifat linier (Gambar 1). Semakin tinggi persentase resistensi $E$. indica yang hidup pada perkebunan kelapa sawit di Kabupaten Batu Bara maka semakin tinggi bobot kering yang dihasilkan. Hal ini disebabkan glifosat tidak dapat menghambat enzim EPSPS pada jaringan kloroplas sehingga pembentukan klorofil tetap berlangsung untuk proses fotosintesis. Hal ini terlihat pada populasi yang resisten hanya mengalami layu sementara pada saat aplikasi glifosat kemudian segar kembali pada besok harinya dilahan percobaan. Hal ini sesuai dengan penelitian Chun et al. (2015) yang menyatakan bahwa enzim EPSPS pada biotipe $E$. indica resisten-glifosat yang berasal dari Cina Selatan dengan cepat merespon herbisida glifosat pada 12 jam setelah terpapar glifosat. Ekspresi mRNA dan protein dari biotipe $E$. indica resisten-glifosat meningkat secara konstan seiring meningkatnya konsentrasi glifosat. Selain itu, Chen et al. (2015) yang menyatakan bahwa pada daun biotipe $E$. indica resisten-glifosat yang berasal dari Chengdu dan Guangzhou, China mengalami penurunan kandungan klorofil dengan jumlah yang sedikit. Penelitian Molin et al. (2013) menyatakan bahwa peningkatan kadar asam shikimat pada daun $E$. indica terpapar glifosat mengindikasi terjadi peningkatan resistensi lima hingga delapan kali dibandingkan populasi sensitif yang berasal dari Washington County, Mississippi. 


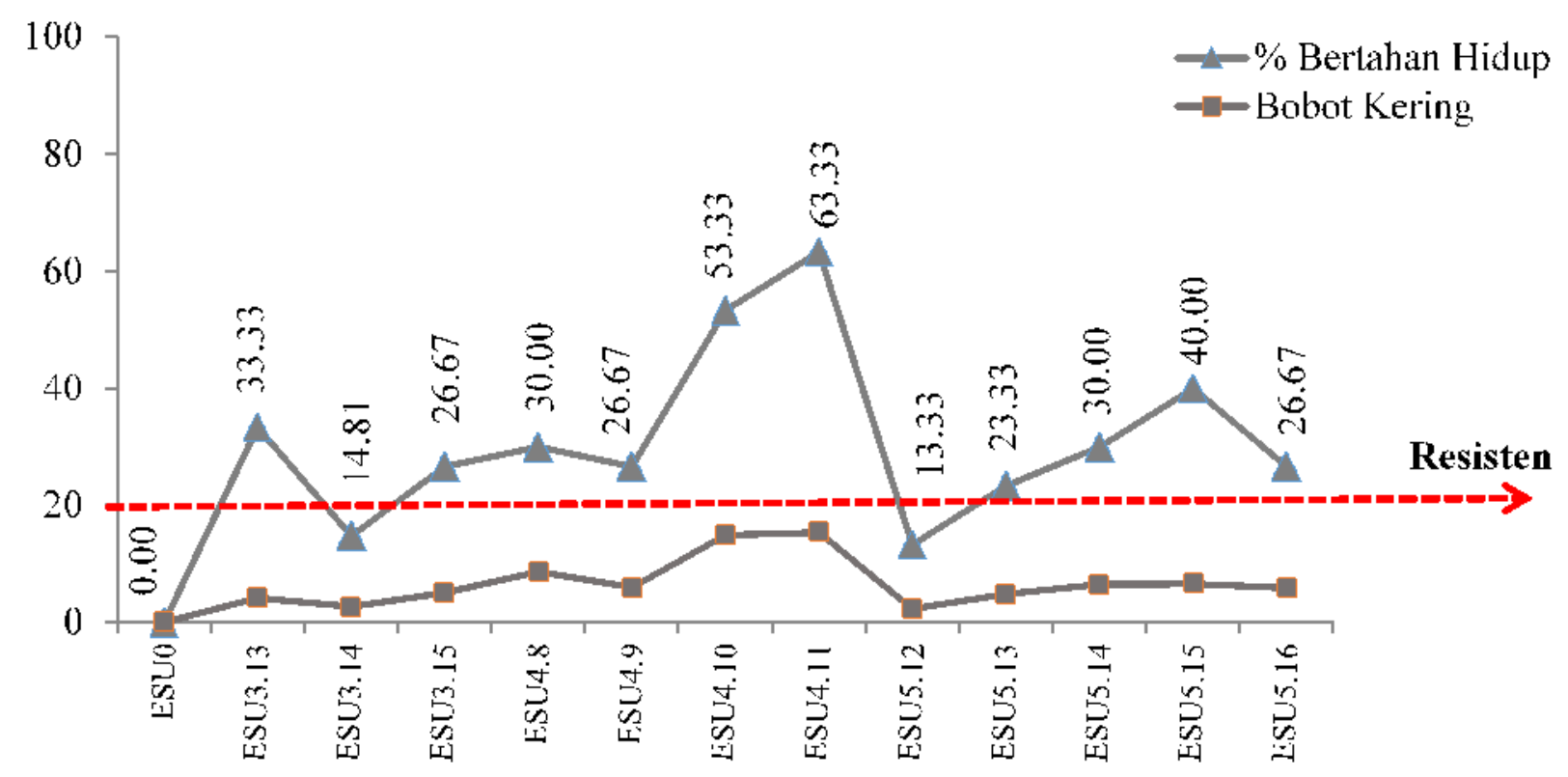

Eleusine indica dari perkebunan kelapa sawit di Kabupaten Batu Bara

Gambar 1. Hubungan populasi $E$. indica yang bertahan hidup dengan bobot kering dari perkebunan kelapa sawit di Kabupaten Batu Bara.

Rataan mortalitas, bobot kering dan klasifikasi resistensi $E$. indica dari beberapa afdeling pada perkebunan kelapa sawit di Kabupaten Batu Bara dapat dilihat Tabel 2. Diperoleh bahwa mortalitas dan bobot kering dari beberapa afdeling pada perkebunan kelapa sawit di Kabupaten Batu Bara berkisar 36,66-86,67\% dan 2,33-15,40 g.
Populasi E. indica yang memiliki mortalitas terendah dan bobot kering tertinggi terdapat pada ESU $_{4.11}$ (afdeling 4 Kebun Tanah Gambus). Populasi E. indica yang tergolong resisten-glifosat pada dosis rekomendasi $720 \mathrm{~g}$ b.a.ha-1 antara lain $\mathrm{ESU}_{3.13}$, $\mathrm{ESU}_{3.15}, \mathrm{ESU}_{4.8}, \mathrm{ESU}_{4.9}, \mathrm{ESU}_{4.10}, \mathrm{ESU}_{4.11}, \mathrm{ESU}_{5.13}$,

Tabel 2. Rataan mortalitas, bobot kering dan klasifikasi resistensi $E$. indica dari perkebunan kelapa sawit di Kabupaten Batu Bara dan populasi sensitif (ESU $)_{0}$.

\begin{tabular}{|c|c|c|c|c|c|c|}
\hline \multirow{2}{*}{ No } & \multirow{2}{*}{ Sampel } & \multirow{2}{*}{ Mortalitas (\%) } & \multirow{2}{*}{ Bobot Kering $\pm \mathrm{SE}^{*}(\mathrm{~g})$} & \multicolumn{3}{|c|}{ Klasifikasi Resistensi* $^{* *}$} \\
\hline & & & & $\mathbf{S}$ & MR & $\mathbf{R}$ \\
\hline 1 & $\mathrm{ESU}_{0}$ & 100,00 & 0,00 & $\sqrt{ }$ & - & - \\
\hline 2 & $\mathrm{ESU}_{3.13}$ & 66,67 & $4,19 \pm 1,97$ & - & - & $\sqrt{ }$ \\
\hline 3 & $\mathrm{ESU}_{3.14}$ & 85,19 & $2,72 \pm 1,39$ & - & $\sqrt{ }$ & - \\
\hline 4 & $\mathrm{ESU}_{3.15}$ & 73,33 & $5,13 \pm 2,73$ & - & - & $\sqrt{ }$ \\
\hline 5 & $\mathrm{ESU}_{4.8}$ & 70,00 & $8,67 \pm 1,33$ & - & - & $\sqrt{ }$ \\
\hline 6 & $\mathrm{ESU}_{4.9}$ & 73,33 & $6,01 \pm 0,57$ & - & - & $\sqrt{ }$ \\
\hline 7 & $\mathrm{ESU}_{4.10}$ & 46,67 & $14,94 \pm 6,70$ & - & - & $\sqrt{ }$ \\
\hline 8 & $\mathrm{ESU}_{4.11}$ & 36,67 & $15,40 \pm 3,53$ & - & - & $\sqrt{ }$ \\
\hline 9 & $\mathrm{ESU}_{5.12}$ & 86,67 & $2,33 \pm 2,03$ & - & $\sqrt{ }$ & - \\
\hline 10 & $\mathrm{ESU}_{5.13}$ & 76,67 & $4,88 \pm 2,53$ & - & - & $\sqrt{ }$ \\
\hline 11 & $\mathrm{ESU}_{5.14}$ & 70,00 & $6,52 \pm 1,36$ & - & - & $\sqrt{ }$ \\
\hline 12 & $\mathrm{ESU}_{5.15}$ & 60,00 & $6,60 \pm 5,24$ & - & - & $\sqrt{ }$ \\
\hline 13 & $\mathrm{ESU}_{5.16}$ & 73,33 & $5,92 \pm 2,81$ & - & - & $\sqrt{ }$ \\
\hline
\end{tabular}

Keterangan : "Standart Error

${ }^{* *} \mathrm{~S}=$ Sensitif(Mortalitas E. indica $>98-100 \%$ ); $\mathrm{MR}=$ Moderat/berkembang Resisten (Mortalitas E. indica $>80$ $-98 \%$ ); R = Resisten (Mortalitas E. indica d" $80 \%$ ). 


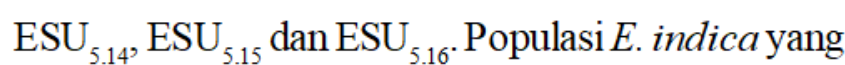
tergolong moderat resisten-glifosat pada dosis rekomendasi $720 \mathrm{~g}$ b.a.ha ${ }^{-1}$ antara lain $\mathrm{ESU}_{3.14}$ dan $\mathrm{ESU}_{5.12}$. Tidak terdapat populasi yang sensitif-glifosat pada dosis rekomendasi 720 g b.a.ha ${ }^{-1}$. Populasi resisten-glifosat ini disebabkan tingginya akumulasi asam shikimat pada jaringan kloroplas $E$. indica. Tingginya akumulasi asam shikimat pada populasi resisten-glifosat ini disebabkan oleh perubahan target site (enzim 5-enolpyruvylshikimate-3-phosphate synthase/EPSPS). Glifosat menghambat enzim EPSPS, mengakibatkan berkurangnya produksiasam amino dan metabolitsekunder sehinggamenghambat pertumbuhan gulma. Kemudian mengganggu fiksasi jalurkarbon dan biokimia secara keseluruhan. Gejala kerusakan yang ditimbulkan tergolong lambat dan berkelanjutan ke seluruhjaringan gulma. Daun gulmamengalami klorosis dari 5 sampai 10 hari setelah aplikasiglifosat kemudian mengalami nekrosis sebelum gulma mati. Hal ini sesuai dengan literatur Monaco et al. (2002) menyatakan bahwa terjadi peningkatan shikimat di jaringan kloroplas disebabkan glifosat. Akumulasi shikimat disebabkan oleh glifosat menghambat enzim 5enolpyruvylshikimate-3-phosphate synthase (EPSPS). EPSPS adalah enzim dalam jalur biosintesis asam amino aromatik yangmengubah shikimate-3-phosphate (S-3-P) menjadi enolpyruvylshikimate-3-phosphate (EPSP) dan akhirnya mengarah pada produksi asam amino, fenilalanin dan tirosin, serta triptofan. Shikimat terbentuk pada perlakuan glifosat karena S-3-P tidak dapat dikonversimenjadiEPSP dan karena S-3-P tidak stabil, maka dikonversi menjadi shikimat yang lebih stabil dan terakumulasi.

Persentase klasifikasi resistensi E. indica pada perkebunan kelapa sawit di Kabupaten Batu Bara dapat disajikan Gambar 3. Diperoleh 10 populasi E. indica yang tergolong resisten-glifosat $(83,33 \%)$, terdapat 2 populasi yang tergolong moderat resisten-glifosat $(16,67 \%)$, dan tidak terdapat populasi yang tergolong sensitif-glifosat ( $0 \%$ ) pada perkebunan kelapa sawit di Kabupaten Batu Bara.

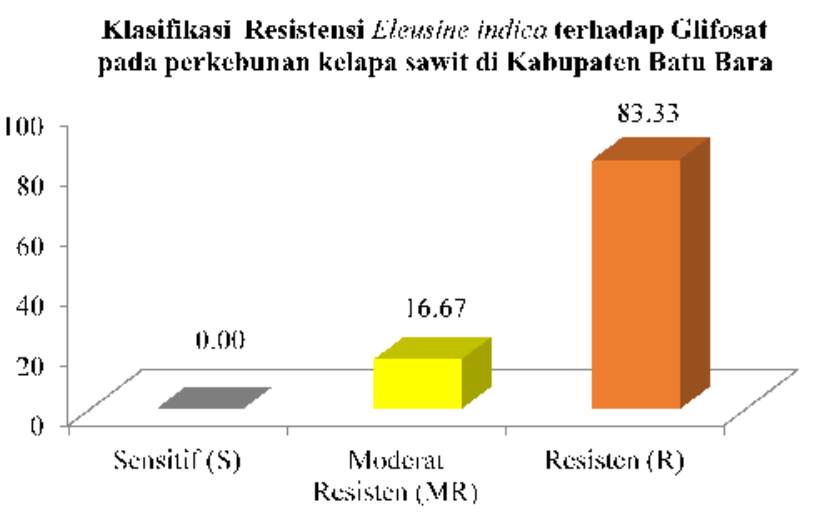

Gambar 3. Persentase klasifikasi resistensi $E$. indica dari perkebunan kelapa sawit di KabupatenBatu Bara.

Informasiresisten inimenggambarkan tingkat kesulitan perkebunan kelapa sawit dalam mengendalikan gulma khususnya $E$. indica. Semakin tinggi persentase resistensi $E$. indica terhdapa glifosat maka semakin sulit untuk mengendalikan gulma tersebut. Kondisi ini sangat mengganggu produksi dan kualitas kelapa sawit. Keberadaan E. indica yang resisten-glifosat pada perkebunan kelapa sawit sudah dilaporkan oleh penelitian sebelumnya di Sumatera Utara. Penelitian Lubis et al. (2012) melaporkan bahwa E. indica dari Kebun Adolina Serdang Bedagai telah resisten $71,70 \%$ terhadap glifosat $720 \mathrm{~g}^{\text {b.a.ha }}{ }^{-1}$ dan indeks resistensi sebesar 7 kali dibandingkan populasi sensitif. Dalimunthe et al. (2015) melaporkan populasi E. indica yang berasal dari Kebun Adolina Serdang Bedagai telah resisten $76,67 \%$ terhadap glifosat $960 \mathrm{~g}$ b.a.ha ${ }^{-1}$ dan indeks resistensi sebesar 7,5 kali dibandingkan populasi sensitif. Selain itu Rahmadhani et al. (2016) juga melaporkan populasi E. indica dari Kebun Adolina Serdang Bedagaitelah resisten $73,30 \%$ terhadap glifosat $960 \mathrm{~g}$ b.a.ha ${ }^{-1}$ dan indeks resistensi sebesar 16,7 kali dibandingkan populasi sensitif, E. indica dari Kebun Sei Daun Labuhanbatu Selatan, Kebun Sawit Seberang Langkat, Kebun Galang dan Kebun Rambutan Serdang Bedagai juga telah resisten masing-masing sebesar $53,30 \%$; $36,70 \% ; 33,30 \%$ dan $40,00 \%$ pada glifosat $480 \mathrm{~g}$ b.a.ha ${ }^{-1}$ serta memiliki indeks resistensi masing-masing sebesar 6,$3 ; 5,1 ; 5,2 ; 5,8$ kali dibandingkan populasi sensitif. Penelitian Syahputra et al. (2016) melaporkan populasi E. indica dari blok afdeling 1 sampai 9 di Kebun Adolina Serdang Bedagai sudah resisten 
terhadap glifosat $480 \mathrm{~g}$ b.a.ha ${ }^{-1}$ dengan klasifikasi 57 populasi resisten $(98,28 \%), 1$ populasi berkembang resisten glifosat $(1,72 \%)$ dan tidak ada terdapat populasi sensitif-glifosat. Penelitian Tampubolon and Purba, $\left(2018^{\text {b }}\right.$ juga melaporkan populasi E. indica yang berasal dari perkebunan kelapa sawit di Kabupaten Langkat sudah resisten-glifosat pada dosis $720 \mathrm{~g}$ b.a.ha ${ }^{-1}$ sebesar $42,11 \%$. Penelitian Tampubolon et al. (2018) juga melaporkan populasi E. indica yang berasal dari perkebunan kelapa sawit di Kabupaten Serdang Bedagai sudah resisten-glifosat pada dosis $720 \mathrm{~g}$ b.a.ha ${ }^{-1}$ sebesar 89,36\% pada Tahun 2017.

Keberadaan E. indica sudah banyak yang melaporkan resisten-glifosat dari tahun 1997 sampai 2017 dari negara Malaysia, Colombia, Bolivia, Cjina, Costa Rica, Mississippi, Tennessee, Argentina, Indonesia, Jepang, dan Brazil. Gulma E. indica sudah resisten glifosat pertama kali pada tahun 1997 di Malaysia (Heap, 2018). Keberadaan E. indica resisten-glifosat pada perkebunan kelapa sawit juga sudah dilaporkan, pertama kali terjadi di pembibitan kelapa sawit pada tahun 2009 di Malaysia kemudian pada tahun 2012 di Indonesia. Hasil penelitian ini sudah menunjukkan bahwa populasi $E$. indica sudah resistenglifosat sebesar 63,33\% pada perkebunan kelapa sawit di Kabupaten Batu Bara. Populasi E. indica yang tergolong moderat resisten-glifosat ini juga dikhawatirkan akan mengalami evolusi dan berpotensi menjadi resisten terhadap herbisida glifosat. Dengan demikian dibutuhkan pengelolaan E. indica resistenglifosat seperti rotasi mode of action herbisida, rotasi mode of action herbisida saat rotasi tanaman, atau pencampuran herbisida dengan berbeda mode of action agar produksi dan kualitas kelapa sawit yang dihasilkan dapat menjadi optimal.

\section{KESIMPULAN}

Populasi E. indica yang paling resisten (63,33\%) pada perkebunan kelapa sawit di Kabupaten Batu Bara terdapat pada $\mathrm{ESU}_{4.11}$ (afdeling 4 Kebun Tanah Gambus). Populasi E. indica yang tergolong resistenglifosat sebesar $83,33 \%$ (10 populasi), tergolong moderat resisten-glifosat sebesar $16,67 \%$ (2 populasi) dan tidak ada populasi yang sensitif-glifosat pada dosis rekomendasi $720 \mathrm{~g}$ b.a.ha ${ }^{-1}$ pada perkebunan kelapa sawit di Kabupaten Batu Bara.

\section{UCAPAN TERIMAKASIH}

Penulis mengucapkan terima kasih kepada Kementerian Riset, Teknologi dan Pendidikan Tinggi Republik Indonesia yang telah mendanai penelitian ini melalui Program Magister menuju Doktor untuk Sarjana Unggul (PMDSU) dan Fakultas Pertanian Universitas Sumatera Utara yang telah mendukung penelitian serta perkebunan kelapa sawit di Kabupaten Batu Bara

\section{DAFTAR PUSTAKA}

Ampong-Nyarko K, SK De Datta and M Dingkuhn. 1992. Physiological Response of Rice and Weeds to Low Light Intensity at Different Growth Stages. Weed Research. 32 (6): 465-472. https:/ /doi.org/10.1111/j.1365-3180.1992.tb01907.x. Chen JC, HJ Huang, SH Wei, CX Zhang and ZF Huang. 2015. Characterization of Glyphosateresistant Goosegrass (Eleusine indica) Populations in China. Journal of Integrative Agriculture. 14 (5): 919-925. https://doi.org/ 10.1016/S2095-3119(14)60910-2.

Chin, H. F. 1979. Weed seed-A potentional source of danger. Proceedings of the Plant Protection Seminar. 22-23 September 1979.

Chun Z, FLi, H Ting-ting, Y Cai-hong, C Guo-qi and T Xing-shan. 2015. Investigating the Mechanisms of Glyphosate Resistance in Goosegrass (Eleusine indica) Population from South China. Journal of Integrative Agriculture. 14 (5): 909918. https://doi.org/10.1016/S20953119(14)60890-X.

Dalimunthe SP, E Purba and Meiriani. 2015. Respons Dosis Biotip Rumput Belulang (Eleusine indica L. Gaertn) Resisten-Glifosat terhadap Glifosat, Parakuat dan Indaziflam. Jurnal Online Agroekoteknologi 3 (2) : 625-633.

Direktorat Jenderal Perkebunan. 2017. Statistik Perkebunan Indonesia Komoditas Kelapa Sawit 2015-2017. Kementerian Pertanian. Jakarta. 81 p.

Heap I. 2018. International Survey of Herbicide Resistant Weeds. Online. http:// www.weedscience.org/Summary/Species.aspx 
Hess M, G Barraljs, H Bleiholder, L Buhr, T Eggers, H Hack and R Stauss. 1997. Use of the Extended BBCH Scale - General for the Descriptions of the Growth Stages of Mono and Dicotyledonous Weed Species. Weed Research 37: 433-441. https://doi.org/10.1046/j.1365-3180.1997.d0170.x.

Ismail BS, TS Chuah, S Salmijah, YT Teng and RW Schumacher. 2002. Germination and Seedling Emergence of Glyphosate-Resistant and Susceptible Biotypes of Goosegrass (Eleusine indica [L.] Gaertn.). Weed Biology and Management 2 (4): 177-185. https://doi.org/ 10.1046/j.1445-6664.2002.00066.x.

Jalaludin A, Q Yu and SB Powles. 2015. Multiple Resistance Across Glufosinate, Glyphosate, Paraquat and ACCase-inhibiting Herbicides in an Eleusine indica Population. Weed Research 55 (1) : 82-89. https://doi.org/10.1111/wre.12118.

Knezevic SZ, A Jhala and T Gaines. Herbicide esistance and Moleculer Aspects. Encyclopedia of Applied Plant Sciences $2^{\text {nd }}$ Edition 3: 455-458. http:// dx.doi.org/10.1016/B978-0-12-3948076.00025-3.

Lubis LA, EPurba and R Sipayung. 2012. Respons Dosis Biotip Eleusine indica Resisten-Glifosat terhadap Glifosat, Parakuat, dan Glufosinat. Jurnal Online Agroekoteknologi 1 (1): 109-123.

Molin W, A Wright and V Nandula. 2013. Glyphosateresistant Goosegrass from Mississippi. Agronomy. 3 (2) : 474-487. https://doi.org/10.3390/ agronomy3020474.

Monaco JT, CS Weller and MF Ashton. 2002. Weed Science Principles and Practices. $4^{\text {th }}$ Edition. Jhon Wiley \& Sons. Inc. New York. p 685.

Mysore KS and V Baird. 1997. Nuclear DNA Content in Species of Eleusine (Graminae): a Critical Reevaluation using Laser Flow Cytometry. Plant Systematics and Evolution. 207: 1-11.
Owen MJ and SB Powles. 2009. Distribution and Frequency of Herbicide-Resistant Wild Oat (Avena spp.) Across the Western Australian Grain Belt. Crop and Pasture Science 60 (1): 25-31. https://doi.org/10.1071/CP08178.

Purba E. 2009. Keanekaragaman Herbisida dalam Pengendalian Gulma Mengatasi Populasi Gulma Resisten dan Toleran Herbisida. Pidato Pengukuhan Jabatan Guru Besar Tetap Universitas Sumatera Utara. Medan. 25 p.

Rahmadhani A, E Purba and DS Hanafiah. 2016.

Respons Lima Populasi Eleusine indica L. Gaertn

Resisten-Herbisida terhadap Glifosat dan Parakuat. Jurnal Online Agroekoteknologi 4 (4): 2245-2254.

SERAS. 1994. Standard Operating Procedures:Plant Biomass Determination. Scientific Engineering Response and Analytical Services. p 1-5. DOI: 10.1201/b 14412-17.

Syahputra AB, E Purba and Y Hasanah.

2016. Sebaran Gulma Eleusine indica L.

Gaertn Resisten Ganda Herbisida pada Satu

Kebun Kelapa Sawit di Sumatera Utara. Jurnal Online Agroekoteknologi 4 (4): 2407-2419.

Tampubolon K and E Purba. 2018.

Konfirmasi Resistensi Eleusine indica terhadap Glifosat pada Perkebunan Kelapa

Sawit di Kabupaten Langkat. Jurnal Pertanian Tropika 5 (2): 276-283.

Tampubolon K and E Purba. 2018 . Screening

Single Resistance of Eleusine indica on Oil

Palm Plantation in Padang Lawas and Tapanuli

Selatan Regency Indonesia. Jurnal Natural 18

(2): 101-106. https://doi.org/10.24815/ jn.v18i2.11223.

Tampubolon K, E Purba, M Basyuni, and DS Hanafiah. 2018. Distribution Mapping of Glyphosate-Resistant Eleusine Indica In Serdang Bedagai Regency. Jurnal Natural 18 ( 3): 127-134. https://doi.org/10.24815/ jn.v0i0.11201. 